\title{
University of Georgia Science Learning Center Methods
}

\section{University of Georgia Research Assistant:}

Rachael Shields, LEED Green Associate, MLA 2019

\section{University of Georgia Research Fellows:}

Dr. Jon Calabria, Associate Professor

Brian Orland, Professor of Geodesign

Alfred Vick, Associate Professor

\section{HDR Firm Liaisons:}

David West, Senior Landscape Architect

Robert Bryant, Planning and Landscape Architecture Discipline Leader

This investigation was conducted as part of the Landscape Architecture Foundation's 2018 Case Study Investigation (CSI) program. CSI matches faculty-student research teams with design practitioners to document the benefits of exemplary high-performing landscape projects. Teams develop methods to quantify environmental, economic and social benefits and produce Case Study Briefs for LAF's Landscape Performance Series.

To cite:

Shields, Rachael, Jon Calabria, Brian Orland, Alfred Vick. "University of Georgia Science Learning Center Methods." The Landscape Performance Series. Landscape Architecture Foundation, 2018. https://doi.org/10.31353/cs13901

The full case study can be found at: https://landscapeperformance.org/case-study-briefs/UGASLC 


\section{Acknowledgments}

We'd like to thank Dr. Roger C. Lowe III of UGA's Warnell School of Forestry and Natural Resources for taking the time to teach us about drone technology and capture imagery. It was a truly inspiring experience that might lead to a few remote pilot certificates! We'd also like to thank Steve Mitchell with UGA's Facilities Management Division, Grounds Department, for assisting in the cost comparison portion of this study. We wouldn't have been able to acquire such detailed data without Steve's assistance.

\section{Environmental Benefits}

- Reduces peak runoff rates by $10 \%$, or 2 cfs, for a 100 -year, 24 -hour storm event.

\section{Methods:}

County ordinance requires that downstream overbank flood and property protection be provided by controlling the peak stormwater discharge rate for 2, 5, 10, 25, and 50-year, 24hour return frequency rainfall events. Engineers modeled times of concentration to develop hydrographs using hydrologic soil group "B" in SCS TR-55 (Travis Pruitt \& Associates, 2014).

Stormwater runoff from the site flows into the campus storm drainage system. The stormwater flow is culverted through the UGA Vet School site and under East Campus Road into an unnamed tributary of the North Oconee River. The point of discharge into the stream channel is approximately 3,000 feet southeast of the project site.

\section{Calculations:}

The net impervious area pre-construction was 66,890 sf. The net impervious area postconstruction is $64,385 \mathrm{sf}$, showing a $3.5 \%$ reduction in impervious area. The project was required to meet the water quality and the 24-hour channel protection provisions of the AthensClarke County Stormwater Management Ordinance [The Code of Athens-Clarke County, Title 5 Utilities, Chapter 5-4 Stormwater, Article 1 Stormwater Management (2004)] due to the development having more than 10,000 sf of impervious area. The stormwater ordinance requires treatment adequate to provide $80 \%$ total suspended solids (TSS) removal for the first 1.2 inches of rainfall for $20 \%$ of the net impervious area for the site because the project is considered a redevelopment. The design of the bioretention cells is based on the Channel Protection Volume rather than the Water Quality Volume. 


\begin{tabular}{|c|c|c|}
\hline STORM EVENT & $\begin{array}{c}\text { TOTAL POST PROJECT } \\
\text { DISCHARGE }\end{array}$ & $\begin{array}{c}\text { TOTAL PREPROJECT } \\
\text { DISCHARGE }\end{array}$ \\
\hline (year) & (cfs) & (cfs) \\
\hline 1 & 5.7 & 6.3 \\
\hline 2 & 7.2 & 8.0 \\
\hline 5 & 11.2 & 12.3 \\
\hline 10 & 12.8 & 14.0 \\
\hline 25 & 16.0 & 18.6 \\
\hline 50 & 19.3 & 21.1 \\
\hline $\mathbf{1 0 0}$ & $\mathbf{2 0 . 9}$ & $\mathbf{2 2 . 9}$ \\
\hline
\end{tabular}

Table 1. Estimated stormwater runoff pre- and post-construction. Source: Travis Pruitt \& Associates.

Percent reduction $=22.9 \mathrm{cfs}-20.9 \mathrm{cfs} / 20.9 \mathrm{cfs}=.09569=10 \%$

\section{Sources:}

Travis Pruitt \& Associates. 2014. "Storm Water Management Plan Report for University of Georgia Science Learning Center."

\section{Limitations:}

Results are modeled and may not reflect actual site conditions.

- Improves water quality by up to $80 \%$, with water samples from bioretention cells having 2.5 Jackson Turbidity Units (JTU) as compared to samples from a nearby area without biorentention cells having $12.5 \mathrm{JTU}$.

\section{Methods:}

A LaMotte Water Quality Monitoring Kit was utilized to evaluate turbidity, alkalinity, nitrate content, and phosphate content from grab samples on March 1, 2017 (Crenshaw et al., 2017). Figure 2 shows the sample sites B and C1 treated by biofiltration within the SLC site. Sample site $A$ was collected from untreated water from a downspout of the SLC roof. Site D and C2 were nearby sites for comparison, with the water samples being collected from water that had not undergone bioretention treatment. 


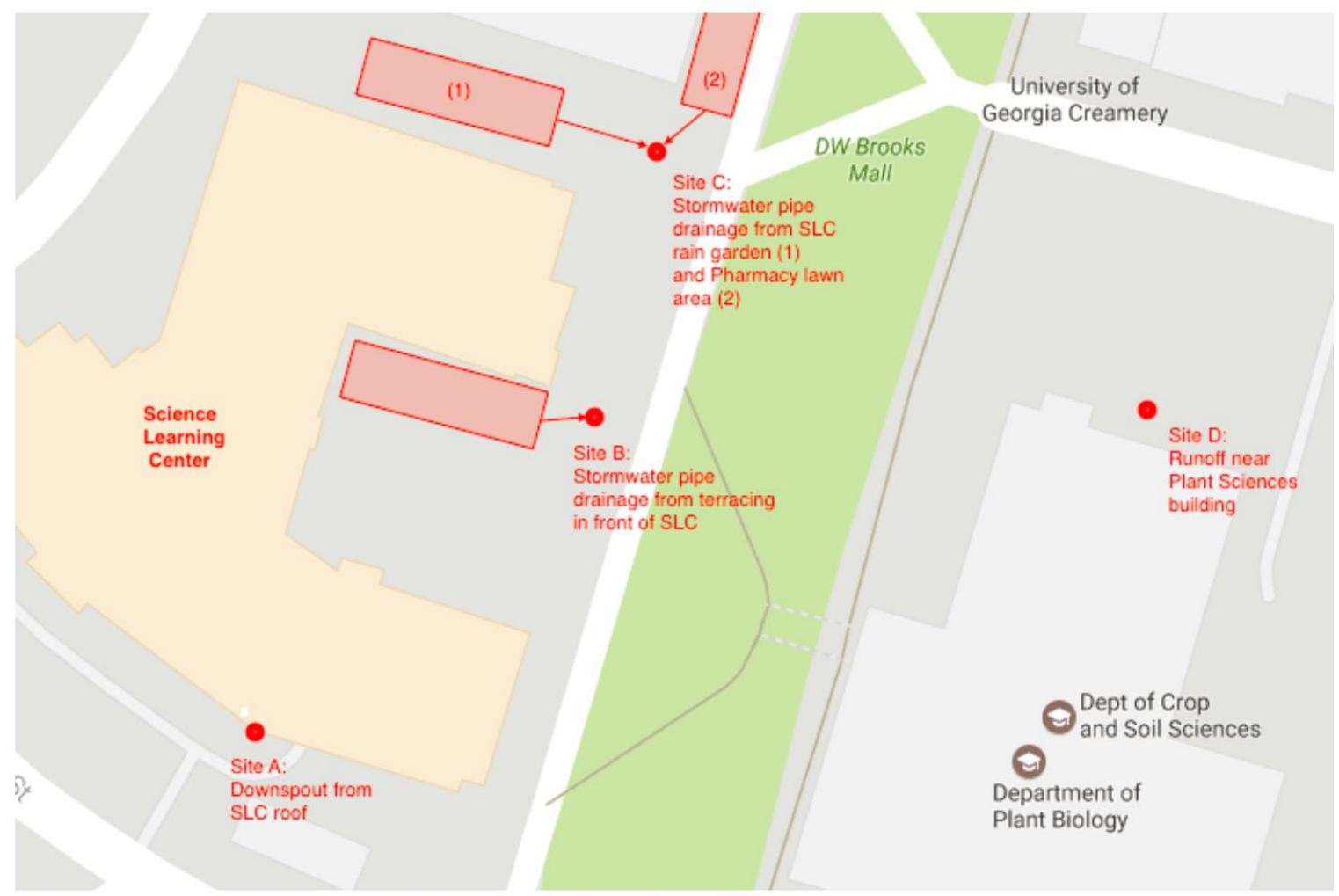

Figure 2. Turbidity test sites. Source: Crenshaw et al., 2017.

\begin{tabular}{|l|l|l|l|}
\hline Sample & Location & Turbidity & Treated \\
\hline A & Downspout from SLC roof & $2.5 \mathrm{JTU}$ & No \\
\hline B & $\begin{array}{l}\text { Stormwater pipe drainage } \\
\text { from terracing in front of SLC }\end{array}$ & $2.5 \mathrm{JTU}$ & Yes \\
\hline C1 & $\begin{array}{l}\text { Stormwater pipe drainage } \\
\text { from SLC rain garden }\end{array}$ & $2.5 \mathrm{JTU}$ & Yes \\
\hline C2 & $\begin{array}{l}\text { Stormwater pipe drainage } \\
\text { from Pharmacy lawn area }\end{array}$ & $4.0 \mathrm{JTU}$ & No \\
\hline D & $\begin{array}{l}\text { Runoff near Plant Sciences } \\
\text { building }\end{array}$ & $12.5 \mathrm{JTU}$ & No \\
\hline
\end{tabular}

Table 2. Turbidity Test Results. Source: Crenshaw et al., 2017. 


\section{Calculations:}

Turbidity was measured in Jackson Turbidity Units.

12.5 JTU - $2.5 \mathrm{JTU} / 2.5=80 \%$ reduction

For reference, the EPA requires that drinking water remains below $1 \mathrm{NTU}$ or $5 \mathrm{NTU}$ for unconventional filtration systems (EPA 2009). NTU is the abbreviation for Nephelometric Turbidity Unit and is the current, more accurate, method for measuring turbidity. The units are comparable to JTU, indicating that the treated water from the SLC site achieves EPA requirements for turbidity in unconventional drinking water.

\section{Sources:}

Crenshaw, Nilah, Samrina Jamal, Akua Kumi-Ansu, Callie Oldfield, Molly Smith, and Reanna Wang. 2017. Monitoring Runoff Water Quality around the Science Learning Center.

EPA. 2009. National Primary Drinking Regulations.

\section{Limitations:}

Flow proportional sampling would be more characteristic of actual conditions than grab samples.

- Sequesters 366 Ibs of atmospheric carbon annually in 69 newly planted trees and 212 Ibs of atmospheric carbon annually in 10 preserved existing trees. The trees intercept an estimated 4,854 gallons of stormwater annually.

\section{Methods:}

i-Tree Eco V6 is a software tool from the U.S. Forest Service, Northern Research Station that provides forestry analysis and benefit assessment (i-Tree Eco v6). The software allows an accessible format for viewing the benefits of an individual tree. The research team entered the species and DBH size of the trees and the surrounding land use into i-Tree. The DBH size and species were verified in the field on May 21, 2018. Results illustrate carbon sequestration in pounds, carbon storage in pounds, and avoided runoff in cubic feet. This process was done in two separate submissions to separate preserved trees from the newly planted trees, $95 \%$ of which are less than 6" caliper. Benefits are expected to increase as trees mature. While our figures demonstrate the value of preserving trees as much as possible through construction, the new plantings contribute to significant future improvements of ecosystem services.

i-Tree also provides monetary value and a projection feature that allows users to see the average annual growth of trees (Table 4). The existing trees are projected to grow an average of 6.5" over 25 years. This number was added to the current tree sizes to create estimated 25year projection numbers. The traditional landscape detailed out in the cost comparison section 
is shown for comparison. These trees only grew an average of 3" over 25 years. As plants mature, some maintenance cost will decrease (less mulch).

Carbon Capture and Storage (CSS) is a crucial element in the process of tackling climate change. Carbon sequestration, which is the removal of carbon dioxide from the air, differs from carbon storage. Carbon storage is the amount of carbon reserved in the above and below ground portions of woody vegetation.

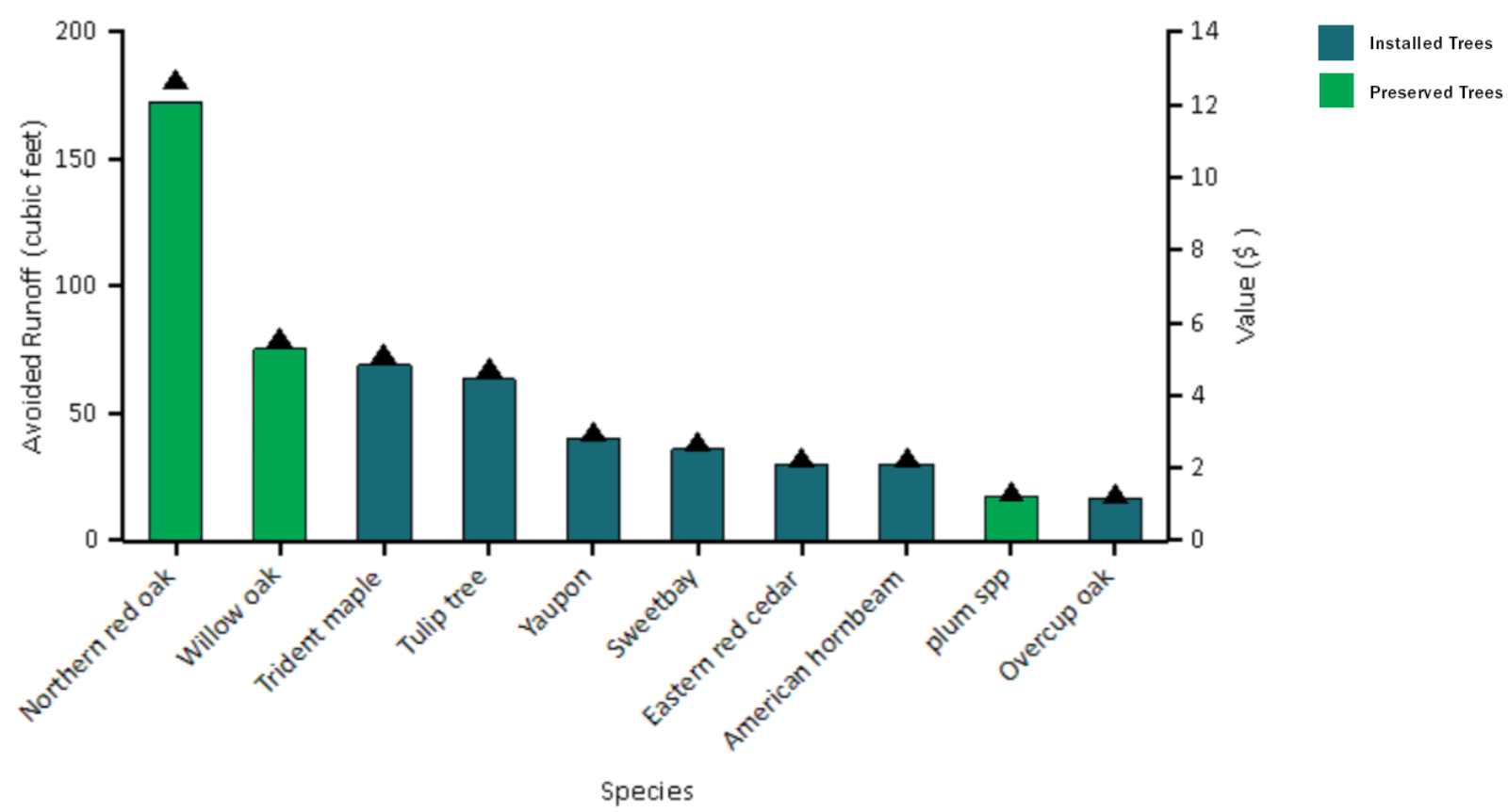

Figure 3. Avoided runoff (cf) by species ranked by greatest overall impact on runoff. Source: iTree Eco v6.

During storm events, a portion of the rain is intercepted by vegetation, transpired or infiltrated. Trees reduce the amount of surface runoff. The total amount infiltrated is 4,854 gallons. In Figure 3 the green bars represent preserved trees. The DBH size of preserved existing Northern Red Oaks and Willow Oaks bring them to the front of the chart; this shows the value of preserving established trees.

\begin{tabular}{|l|l|l|l|}
\hline \multicolumn{2}{|l|}{ Preserved Trees } & \multicolumn{2}{l|}{ Installed Trees } \\
\hline 1 & Juniper spp. (Juniperus) 3" & 2 & Trident Maple (Acer buergerianum) 3.5" \\
\hline 2 & Holly spp. (llex) 4" & 8 & Trident Maple (Acer buergerianum) 3" \\
\hline 2 & Cedar spp. (Cedrus) 4" & 3 & Musclewood (Carpinus Caroliniana) 3" \\
\hline
\end{tabular}




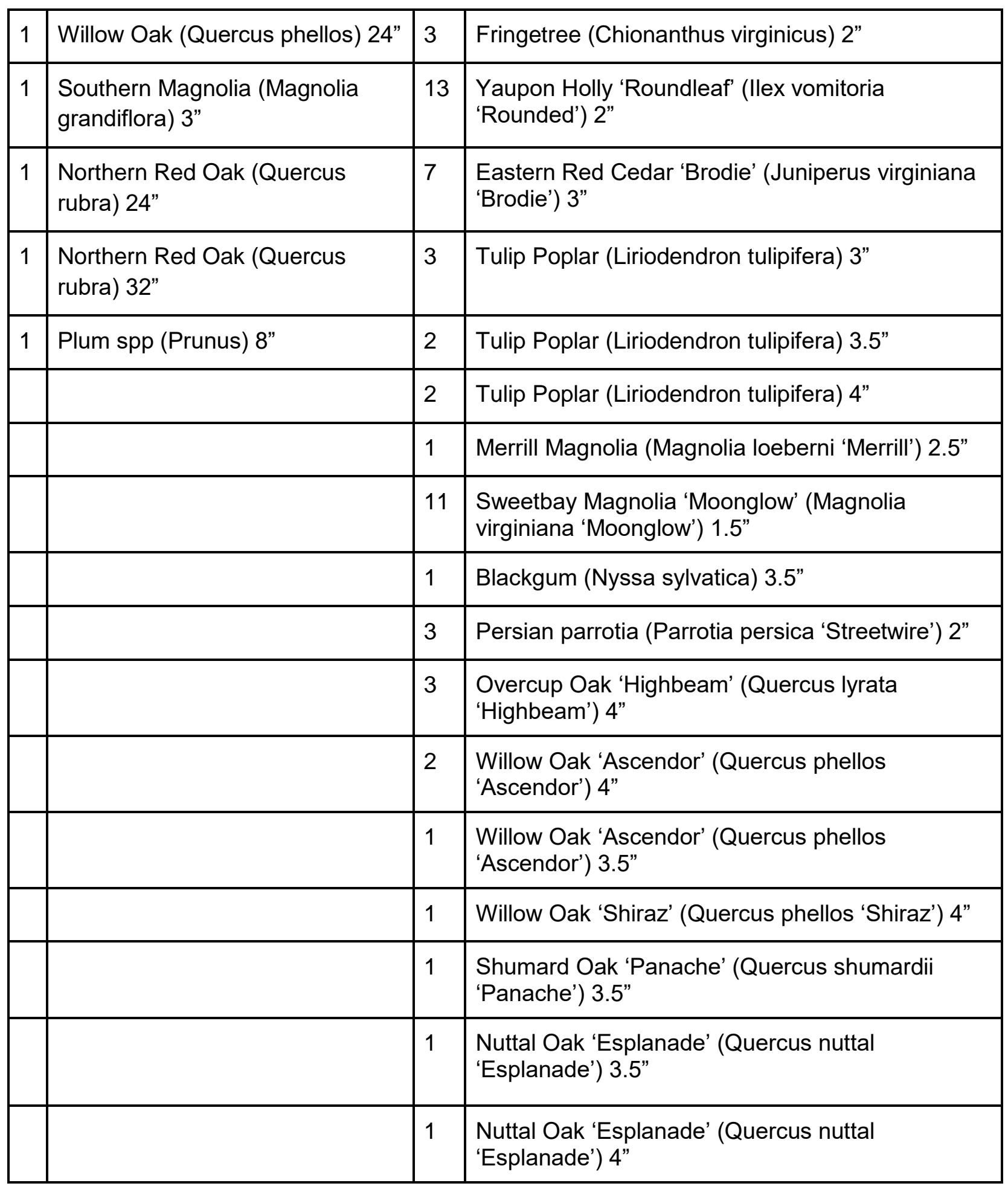

Table 3. Preserved and newly planted trees. 


\section{Calculations:}

i-Tree's database has values for different tree and size types. The calculation used to determine $\mathrm{CO}_{2}$ sequestered per tree $(\mathrm{kg})=$ tree mass $(\mathrm{kg}$ of fresh biomass) $\times 65 \%$ (dry mass) $\times 50 \%$ (carbon \%) x $3.67 \times 120 \%$.

There are 69 newly planted trees on site and ten preserved trees, for a total of 79 trees. Annually, the 79 trees sequester 366.6 pounds, or 0.183 tons of carbon.

The current estimated carbon storage on site is 5.009 tons for preserved trees and .486 tons for newly planted trees (i-Tree Eco v6).

Avoided runoff is estimated based on local weather from the nearest weather station. The total annual precipitation in 2015 was 68.7 inches. The avoided runoff value is calculated based on the price of $\$ 0.07$ per cubic foot, the value achieved through savings in "gray" stormwater infrastructure.

$649 \mathrm{cu} \mathrm{ft}=4854.86$ gallons .

\begin{tabular}{|l|c|c|c|c|}
\cline { 2 - 5 } \multicolumn{1}{c|}{} & \multicolumn{2}{c|}{ Actual Landscape } & \multicolumn{2}{c|}{ Traditional UGA Landscape } \\
\cline { 2 - 5 } \multicolumn{1}{c|}{} & $\mathbf{2 0 1 8}$ & $\mathbf{2 5}$ Year Projection & $\mathbf{2 0 1 8}$ & $\mathbf{2 5}$ Year Projection \\
\hline carbon storage & $\$ 711$ & $\$ 2,170$ & $\$ 11.10$ & $\$ 74.60$ \\
\hline avoided runoff & $\$ 42.90$ & $\$ 138$ & $\$ 5.08$ & $\$ 13$ \\
\hline pollution removal & $\$ 7.69$ & $\$ 25.10$ & $\$ 1.06$ & $\$ 2.71$ \\
\hline carbon sequestration & $\$ 23.50$ & $\$ 75.50$ & $\$ 1.95$ & $\$ 6.66$ \\
\hline TOTAL & $\$ 785$ & $\$ 2,409$ & $\$ 19$ & $\$ 97$ \\
\hline
\end{tabular}

Table 4. Current and projected values of Science Learning Center trees and comparison to traditional UGA landscape. Source: based on data provided by i-Tree Eco v6.

\section{Sources:}

i-Tree Eco v6. Accessed July 2, 2018. https://www.itreetools.org/eco/index.php

\section{Limitations:}

The i-Tree results do not take into account any of the shrubs or groundcovers on the site.

\section{Social Benefits}

\section{Overall Methods:}

A survey was developed (guided by precedents from Olin Partnership) to assess site user behavior and enjoyment (Olin Partnership, Email to Research Fellow, April 5, 2018). A convenience sample of site users was conducted on Monday, Tuesday, and Saturday from 9am to $5 \mathrm{pm}$. Respondents completed a digital survey to assess their perceptions of the site based on 
34 questions shown in the Appendix, which also included demographic questions. Results from respondents $(\mathrm{N}=89)$ were summarized (Qualtrics and JMP 13.2.1).

Overall Sources:

Survey Questions (see appendix A)

\section{Overall Limitations:}

Due to the CSI program schedule and the necessity of IRB review, the survey was administered in the summer semester. The sample size was limited due to the number of hours the research team could spend in the field. Additional respondents would improve the reliability of the statistical results.

\section{- Creates a safe environment according to $96 \%$ of 89 survey respondents.}

- Creates an environment for learning according to $84 \%$ of 89 survey respondents who agree that it is a good place to read or study.

Notable results of the survey regarding ways in which the landscape contributes to the academic and social value of the site are as follows:

- $84 \%$ of respondents $(\mathrm{N}=89)$ agree or strongly agree that this is a good place to read or study

- $66 \%$ of respondents $(\mathrm{N}=88)$ visit the site more than once a week.

- $75 \%$ of respondents $(\mathrm{N}=89)$ agree or strongly agree that this is a good place to hang out.

- $72 \%$ of respondents $(\mathrm{N}=89)$ agree or strongly agree that this place encourages interaction with others.

- $96 \%$ of respondents $(\mathrm{N}=89)$ agree or strongly agree that they feel safe in this place.

- $69 \%$ of respondents $(\mathrm{N}=89)$ agree or strongly agree that the outdoor area provides a real sense of escape and relief from being indoors.

- $89 \%$ of respondents $(\mathrm{N}=89)$ agree or strongly agree the area is overall fairly quiet and free from obnoxious noises.

- $69 \%$ of respondents $(\mathrm{N}=89)$ agree or strongly agree there are at least one or more choices of private outdoor places to sit.

- $77 \%$ of respondents $(\mathrm{N}=89)$ agree or strongly agree there are comfortable places to linger to meet or greet people.

- $93 \%$ of respondents $(\mathrm{N}=89)$ say the outdoor space can be easily viewed and reached from well used indoor spaces.

- $80 \%$ of respondents ( $\mathrm{N}=89$ ) have attended some college and $100 \%$ have graduated from high school. 


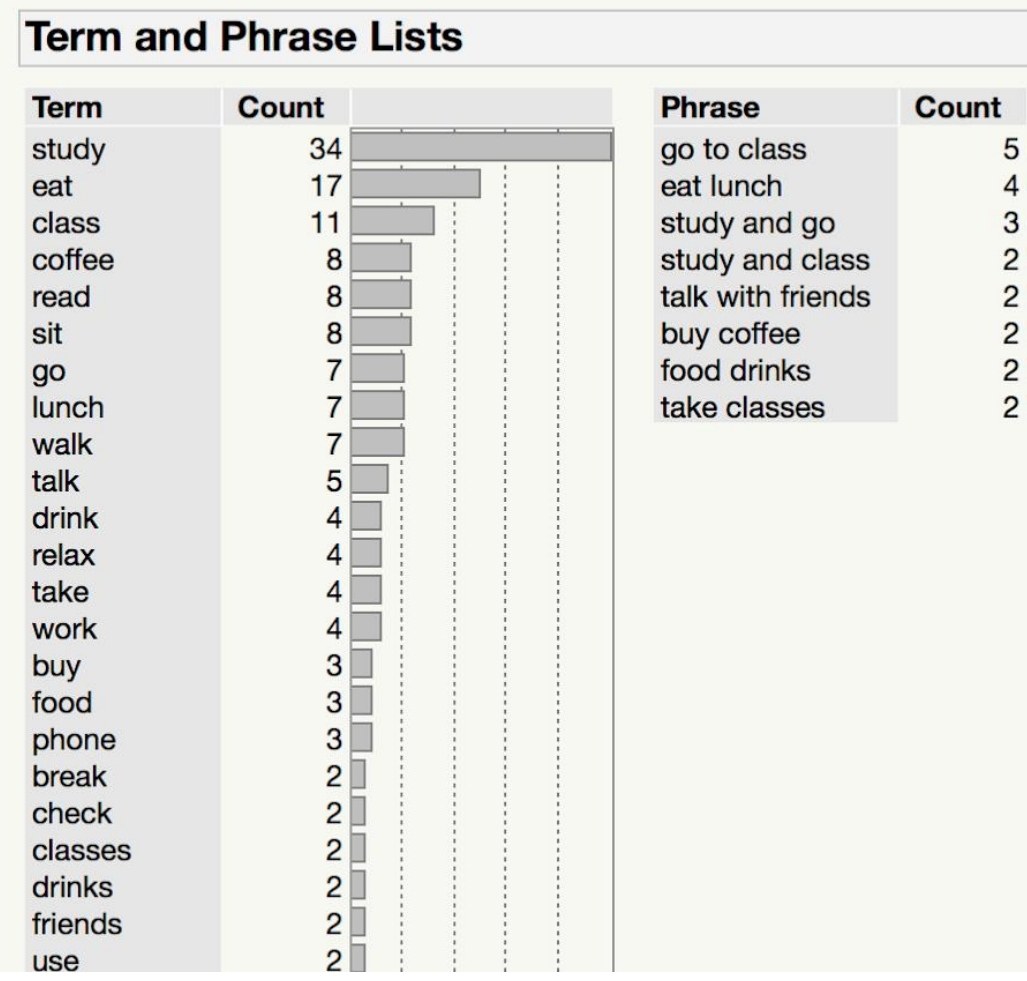

Figure 4. Term and phrase lists showing frequency of responses to "what types of things do you do in this place?" Source: JMP.

Figure 4 shows respondents ( $N=89)$ listed studying, eating, and going to class as the primary reasons they are visiting the site. A total of 260 descriptive terms were used by respondents to answer "what types of things do you do in this place?"

\section{Other Social Observation:}

- Provides space for users, with the mean age of respondents being 27 years old and $65 \%$ of the respondents being between the ages of 18 and $25, c 2(2, N=86)=$ $1.41, p=.49$. 


\begin{tabular}{|c|c|c|c|}
\hline \multicolumn{4}{|c|}{$\begin{array}{l}\text { How often do you come here each } \\
\text { week? }\end{array}$} \\
\hline \multirow[t]{2}{*}{\begin{tabular}{|l|} 
Count \\
Total \% \\
Col \% \\
Row \% \\
$18-25$ \\
\end{tabular}} & $\begin{array}{l}1 \text { or } \\
\text { Less }\end{array}$ & $\begin{array}{l}2+ \\
\text { Times }\end{array}$ & Total \\
\hline & 17 & 39 & \\
\hline & 19.77 & 45.35 & 65.12 \\
\hline & 58.62 & 68.42 & \\
\hline & 30.36 & 69.64 & \\
\hline \multirow{4}{*}{$25-35$} & 5 & 10 & 15 \\
\hline & 5.81 & 11.63 & 17.44 \\
\hline & 17.24 & 17.54 & \\
\hline & 33.33 & 66.67 & \\
\hline \multirow[t]{4}{*}{$35+$} & 7 & 8 & 15 \\
\hline & 8.14 & 9.30 & 17.44 \\
\hline & 24.14 & 14.04 & \\
\hline & 46.67 & 53.33 & \\
\hline \multirow[t]{2}{*}{ Total } & 29 & 57 & 86 \\
\hline & 33.72 & 66.28 & \\
\hline
\end{tabular}

Figure 5. Visitation Frequency / Age Bracket. Source: JMP.

Users between the ages of 18-25 are visiting the site the most often. They are also staying the longest with $53 \%(\mathrm{~N}=86)$ of them staying more than an hour.

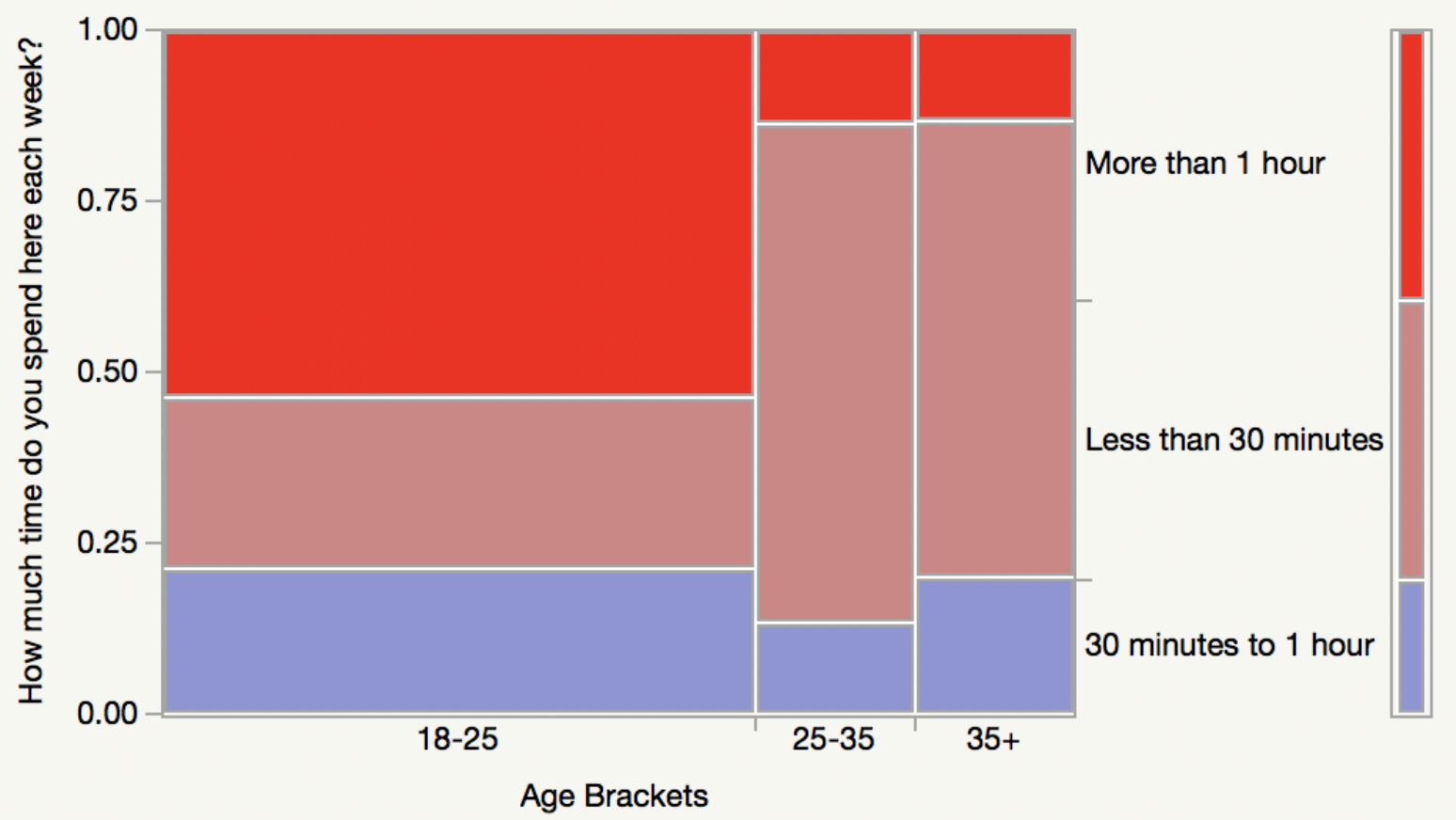

Figure 6. Mosaic plot of time spent by age category. Source: JMP. 


\section{Cost Comparison Methods}

The Science Learning Center's installed plant material, mulch, and first year of maintenance cost \$124,282. The same costs for hypothetical typical UGA landscape on the same site are estimated at \$95,866, a difference of $\$ \mathbf{2 8 , 4 1 6}$. The higherperformance landscape that was installed cost more, but benefits shown throughout the rest of this case study like plant biodiversity, carbon sequestration, and runoff reduction help to offset the additional cost.

The study area of the Science Learning Center's landscape is 43,358 sf, almost 1 acre. Comparing the existing landscape planting plan with a hypothetical more traditional plan similar to other campus landscapes (Figures $7 \mathrm{a}$ and $7 \mathrm{~b}$ ) illustrates several key cost differences. The built SLC landscape contains large areas of shrubs and groundcovers in mulched beds without turf. Materials include 79 trees and 5,003 shrubs, groundcovers, and herbaceous perennials. Price totals shown in the table below were based on the estimate provided by the contractor for these materials. Mulch price was calculated as $10 \%$ of the plant material cost.

For the cost comparison a "traditional" landscape plan was created for the same site, consisting of 23 trees, 216 shrubs, and 31,414 sf of turf (University of Georgia Facilities Management Division, 2018). These numbers were based on similar nearby sites like the College of Education, College of Veterinary Medicine, and the U.S. Forest Service Southern Research Station. Prices were averaged from the estimate provided for the installed landscape costs; \$48/shrub, \$755/tree, and \$2/sf sod (University of Georgia Facilities Management Division, 2018). The mulch price was calculated as $10 \%$ of the plant material cost.

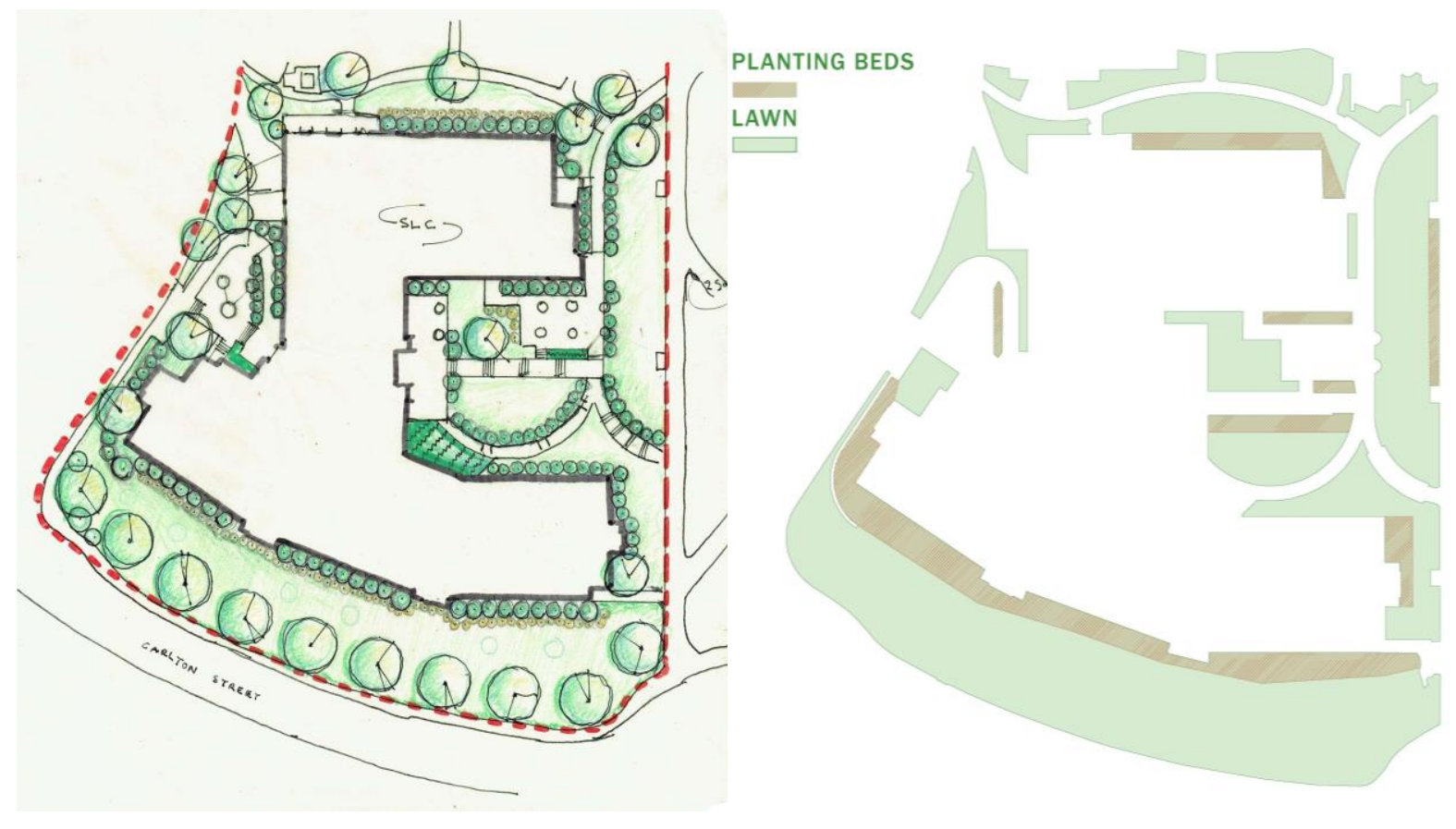


Figures 7a and 7b. Typical UGA landscape plan applied to the SLC's site. Source: University of Georgia's Facilities Management Division.

1 Acre Site:

Existing UGA SLC as installed

Plant Material: $\$ 107,464$

Mulch: $\$ 10,746$

Total: $\$ 118,210$

Hypothetical "Traditional" UGA landscape

Plant Material: $\$ 27,733$

Sod: $\$ 62,828$

Mulch: $\$ 2,773$

Total: $\$ 93,334$

Difference: $\$ 31,637$

Average monthly maintenance hours for each landscape (installed vs. traditional) provided by campus facilities management illustrate that more than twice the amount of time, and therefore more money, is required to maintain the existing landscape at this early stage. However, the inherently lower-maintenance vegetation plan with native and drought-tolerant plants will fill in and require less resources in the future (Table 1).

\begin{tabular}{|l|l|r|l|r|}
\hline & "traditional" landscape & existing landscape & \\
\hline & task & hours & task & hours \\
\hline january & leaf removal, post-weed control & 48 & leaf removal, post-weed control & 96 \\
\hline february & mulching & 4 & mulching & 96 \\
\hline march & pre-emergent, aerating lawn & 2 & pre-emergent & 1 \\
\hline april & post-emergent, scalping lawn & 12 & post-emergent & 1 \\
\hline may & cut grass, monitor weeds, tree work & 18 & monitor weeds, pruning & 41 \\
\hline june & cut grass, monitor weeds & 12 & monitor weeds & 1 \\
\hline july & cut grass, monitor weeds & 12 & monitor weeds & 1 \\
\hline august & cut grass, mulching & 18 & mulching, pruning & 136 \\
\hline september & pre-emergent, cut grass, post-weed control & 13 & pre-emergent & 1 \\
\hline october & cut grass, leaf removal, post-weed control & 12 & leaf removal, post-weed control & 12 \\
\hline november & leaf removal, cut grass & 12 & leaf removal & 24 \\
\hline december & leaf removal, post-weed control & 48 & leaf removal, post-weed control & 96 \\
\hline & TOTAL & 211 & TOTAL & 506 \\
\hline & Cost at \$12/hour & 2532 & Cost at \$12/hour & 6072 \\
\hline
\end{tabular}

Table 5. Person-hour comparison between 1 acre of the installed SLC landscape and 1 acre of typical UGA landscapes. Source: University of Georgia's Facilities Management Division.

Plant-related costs including installation + first year of maintenance

SLC as built: $\$ 118,210+\$ 6,072=\$ 124,282$

Hypothetical typical landscape: $\$ 93,334+\$ 2,532=\$ 95,866$

$124,282-95,866=\$ 28,416$

The benefits shown throughout the rest of this document help make up the additional cost and costs for the installed SLC landscape are expected to diminish as it matures. UGA's Facilities 
Management Division will continue to analyze maintenance costs and plans to update the SLC's landscape by replacing failing material and adding additional vegetation.

\section{Sources:}

University of Georgia Facilities Management Division. 2018.

\section{Limitations:}

The tree count of the installed landscape was verified on May 21, 2018; however, shrub, groundcover, and herbaceous perennial counts were based of the contractor's estimate.

\section{Appendix A \\ Qualtrics Survey}

LAF Outdoor Space Evaluation

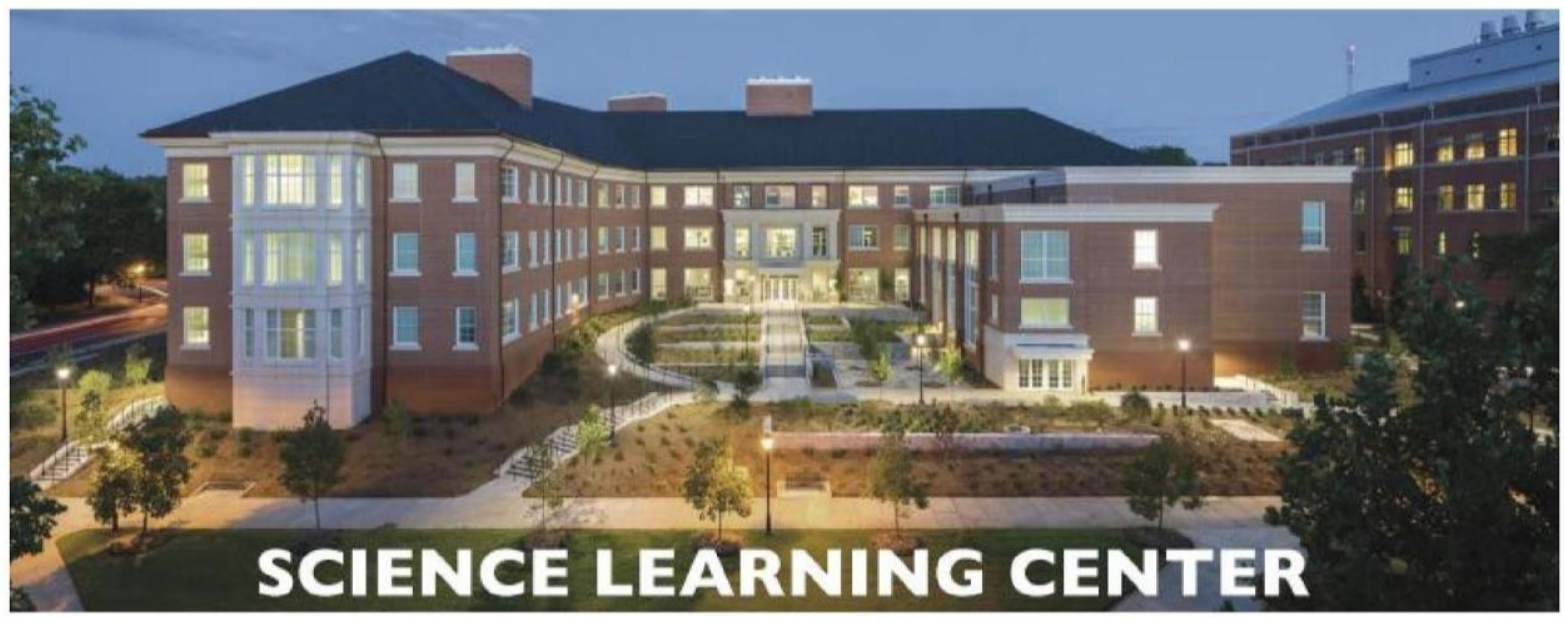

Consent Letter

$4 / 23 / 2018$

Dear Outdoor Space User:

Your input on this outdoor space is important to research we are conducting. I am a graduate student under the direction of Dr. Jon Calabria in the College of Environment and Design at The University of Georgia. I invite you to participate in a research study entitled LAF Outdoor Space Evaluation that is being conducted under the auspices of Landscape Architecture Foundation to understand your perception of this space. You must be 18 years of age or older to participate.

Your participation will involve taking a questionnaire that may take about 10 minutes. Your involvement in the study is voluntary, and you may choose not to participate or to stop at any time without penalty or loss of benefits to which you are otherwise entitled. If you decide to stop or withdraw from the study, the information/data collected from or about you up to the point of your withdrawal will be kept as part of the study and may continue to be analyzed. Your data is confidential and only researchers will have access to data stored on password protected devices. The results of the research study may be 
published, but your name or any identifying information will not be used. In fact, the published results will be presented in summary form only.

The findings from this project may provide information on how you and others perceive this space. There are no known risks or discomforts associated with this research.

If you have any questions about this research project, please feel free to contact me at 706-542-1816 or send an e-mail to rachael.shields@uga.edu. Questions or concerns about your rights as a research participant should be directed to The Chairperson, University of Georgia Institutional Review Board; telephone (706) 542-3199; email address irb@uga.edu. By checking the box below, you are agreeing to participate in the above described research project.

Thank you for your consideration and providing your insight on this outdoor space. Please keep this letter for your records. Sincerely,

Rachael Shields

Agree and continue

Disagree

$\mathrm{O}$

STEP 1: Think about the outdoor area you are in - First, decide on the boundaries of the outdoor space to be evaluated. (Include everything that is viewable, even if beyond the space itself.)

STEP 2: Walk and sit in the area - Walk around slowly, test any furniture, look at the area from different positions.

STEP 3: Please tell how you feel in this space

Do you spend time here with others or alone?

Alone

With 1 or 2 Others

With Larger Groups

O

$\mathrm{O}$

O 
How often do you come here each week?
Daily
2-4 Times
1 or Less
O
O
$\mathrm{O}$

How much time do you spend here each week?

$\begin{array}{ccc}\text { More than } 1 \text { hour } & 30 \text { minutes to } 1 \text { hour } & \text { Less than } 30 \text { minutes } \\ \mathrm{O} & \mathrm{O} & \mathrm{O}\end{array}$

For the next four questions, please provide just two or three key words in each case

What attracts you to this place?

What types of things do you do in this place?

What do you like about this place? 
For these questions, please indicate whether you agree or disagree with the statement.

$\begin{array}{lccccc} & \begin{array}{c}\text { Strongly } \\ \text { Agree }\end{array} & \text { Agree } & \text { Neutral } & \begin{array}{c}\text { Disagree } \\ \text { Disagree }\end{array} \\ \begin{array}{l}\text { I feel safe in this place } \\ \begin{array}{l}\text { This outdoor area } \\ \text { provides a real sense of } \\ \text { escape and relief from } \\ \text { being indoors }\end{array}\end{array} & 0 & 0 & 0 & 0 & 0 \\ \begin{array}{l}\text { This a good place to read } \\ \text { or study }\end{array} & 0 & 0 & 0 & 0 & 0 \\ \begin{array}{l}\text { I avoid this place } \\ \begin{array}{l}\text { This is a good place to } \\ \text { hang out }\end{array}\end{array} & 0 & 0 & 0 & 0 & 0 \\ \begin{array}{l}\text { This place discourages } \\ \text { interaction with others }\end{array} & 0 & 0 & 0 & 0 & 0 \\ \end{array}$

STEP 4: Please evaluate the area

for these questions, please indicate whether you agree or disagree with the statement

$\begin{array}{cccc}\begin{array}{c}\text { Strongly } \\ \text { Agree }\end{array} \text { Agree } \quad \text { Neutral } & \text { Disagree } & \begin{array}{c}\text { Strongly } \\ \text { Disagree }\end{array}\end{array}$

This area includes abundant healthy green plants (vs. large areas of paving)

$\begin{array}{lllll}0 & 0 & 0 & 0 & 0\end{array}$


From this area, you can watch

human activities, nearby streets and traffic

There are enough tables for reading, working, and eating

The area is overall fairly quiet, and free from obnoxious noises

This outdoor space can be easily viewed and reached from well-used indoor spaces

There are nearby restrooms, with access to a drinking fountain

There is plenty of seating available with choices to sit in sun or shade

There is a diverse mix of trees, vines, flowers and shrubs that attract wildlife

There are pleasant views with interesting things to see

Paving is level, smooth, no deep cracks, and with handrails where needed

There are sidewalks partly or fully shaded from mid-day or hot afternoon sun

Seating surfaces are comfortably shaped and of materials that do not get too hot or cold

There are comfortable places to linger to meet or greet people
Strongly

Agree

Agree

Neutral

Disagree

Strongly

Disagree

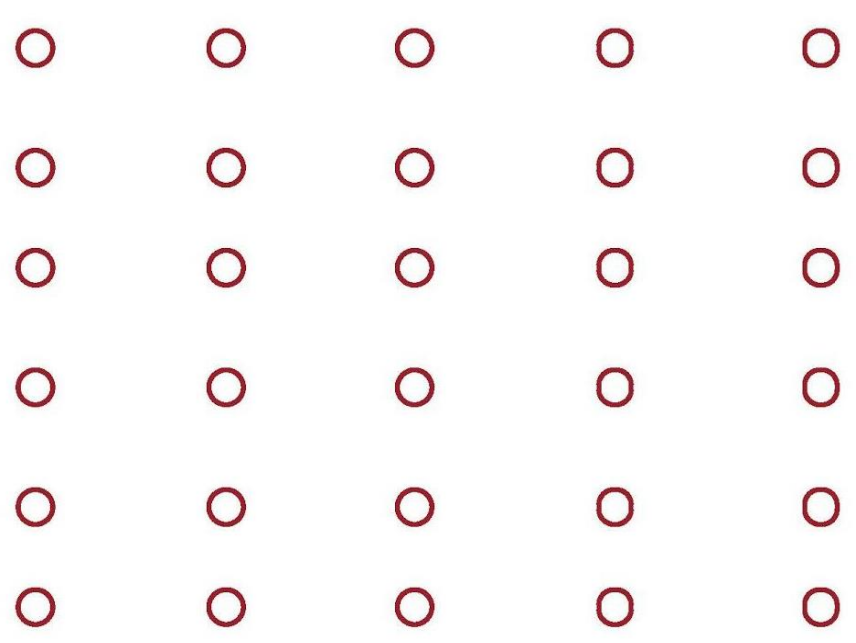

O

0

0

O 0

O

0

0

$0 \quad 0$

0

0

0

$0 \quad 0$

O

0

0

O 0

0

0

O 0
0

0 
There are at least one or more choices of private outdoor places to sit

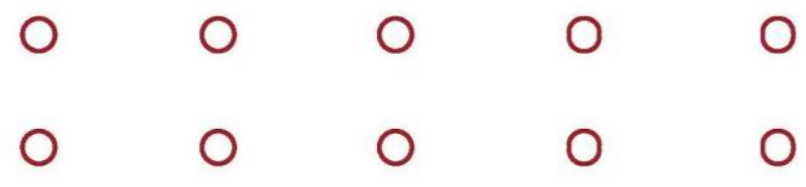

There are paths or sidewalks of different lengths

\section{STEP 5: Please tell us about yourself}

What is your age? (in years)

What gender do you identify with?
O Male
O Female
Other

I identify my ethnicity as:
Asian
O Black/African
Caucasian 


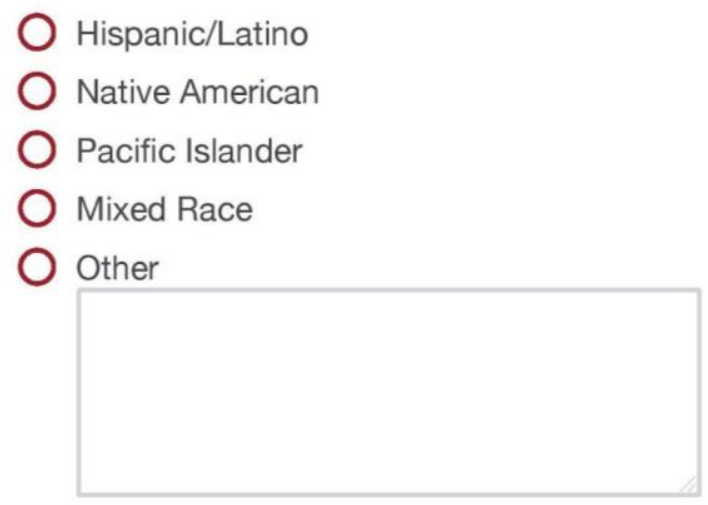

What is the highest level of education you have completed?
Did not finish high school
High school or GED
Attended college but no degree
O Associate's or vocational degree
College bachelor's degree
Some graduate work
$\mathrm{O}$ Graduate degree, Masters or PhD

What is the zip code of your primary residence?

Is there anything else you'd like to share about your experience in this space?

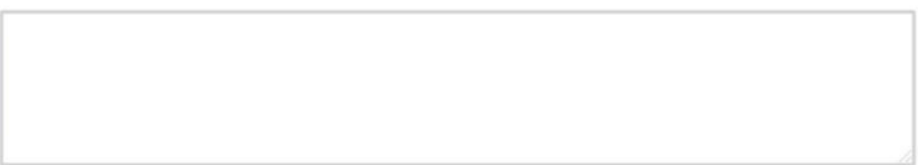

THANK YOU for helping us with this survey - please contact us at Rachael.Shields@uga.edu with any questions.

(C2018, Orland, Calabria, Shields, Vick, College of Environment and Design, University of Georgia, Athens, GA. Adapted from: (C2014, Susan Rodiek, Center for Health Systems \& Design, Texas A\&M University, College Station, TX. AND OLIN and Partners, Washington Canal Park Post-Occupancy Evaluation IRB: 